Article type : Regular Manuscript

\title{
High carbon storage in carbon limited trees
}

\author{
Raphael Weber ${ }^{*}$, \\ Arthur Gessler ${ }^{2,3}$ orcid.org/0000-0002-1910-9589, \\ Günter Hoch ${ }^{1}$ orcid.org/0000-0003-0985-9746
}

${ }^{1}$ Department of Environmental Sciences - Botany, University of Basel, Schönbeinstrasse 6, 4056 Basel, Switzerland

${ }^{2}$ Swiss Federal Institute for Forest, Snow and Landscape Research (WSL), 8903 Birmensdorf, Switzerland

${ }^{3}$ Institute of Terrestrial Ecosystems, ETH Zürich, 8092 Zürich, Switzerland

*Corresponding author: r.weber1 @ gmx.ch, +41612073502

\section{Summary}

- The concentrations of nonstructural carbohydrates (NSC) in plant tissues are commonly used as an indicator of total plant carbon (C) supply; but some evidence suggests the possibility for high NSC concentrations during periods of C-limitation. Despite this uncertainty, NSC dynamics have not been investigated experimentally under long-term Climitation.

-We exposed saplings of 10 temperate tree species differing in shade tolerance to $6 \%$ of ambient sunlight for $3 \mathrm{yr}$ to induce C-limitation, and also defoliated one species, Carpinus betulus, in the third season. Growth and NSC concentrations were monitored to determine C allocation.

- Shade strongly reduced growth, but after an initial two-fold decrease, NSC concentrations of shaded saplings recovered to the level of unshaded saplings by the third season. NSC concentrations were generally more depleted under shade after leaf flush, and following This article has been accepted for publication and undergone full peer review but has not been through the copyediting, typesetting, pagination and proofreading process, which may lead to differences between this version and the Version of Record. Please cite this article as doi: $10.1111 / \mathrm{nph} .15599$

This article is protected by copyright. All rights reserved. 
herbivore attacks. Only under shade, artificial defoliation led to mortality and depleted NSC concentrations in surviving individuals.

-We conclude that, irrespective of shade tolerance, C-storage is maintained under prolonged shading, and thus high NSC concentrations can occur during C-limitation. Yet, our results also suggest that decreased NSC concentrations are indicative of C-limitation, and that additional leaf loss can lead to lethal C-shortage in deep shade.

\section{Keywords}

carbon (C) allocation, carbon (C) starvation, light limitation, source-sink relations, starch, sugar, relative growth rate, productivity

\section{Introduction}

Trees make up c. 90\% of the global biomass carbon (C) pool (Olson et al. 1983). They generally store large amounts of freely available C-reserves, commonly termed non-structural carbohydrates (NSC, i.e. free sugars and starch), which can exceed 6 tons per ha in forests (Hoch et al. 2003, Würth et al. 2005). These carbohydrates are often quantified to estimate a plant's C-balance, assuming that NSC concentrations are controlled by the net-balance between photo-assimilation and C-usage (respiration, growth and other sinks; Körner 2003). Understanding the C-balance of a single tree may answer fundamental questions regarding tree performance under different environmental conditions, such as elevated $\mathrm{CO}_{2}$ levels or drought (Hoch 2015). Unfortunately, tree C-balance cannot be easily assessed by conventional methods like gas-exchange measurements.

Currently, considerable debate remains as to how NSC concentrations in trees are influenced by their C source-sink balance (Lacointe et al. 2004, Palacio et al. 2008, Sala et al. 2011, Galiano et al. 2017), and as a result, whether they can be used as a C-balance indicator (Wiley and Helliker 2012, Palacio et al. 2014). Perennial species like trees rely on stored C to survive long periods of negative C-balance (e.g. dormant season, re-growth after damage). In temperate tree species, NSC pools are rebuilt towards the end of each season, even after different $\mathrm{C}$-limiting treatments like defoliation, low atmospheric $\mathrm{CO}_{2}$ concentrations, darkness, or a combination of these factors (Palacio et al. 2012, Wiley et al. 2013, Schmid et 
al. 2017, Weber et al. 2018). Unfortunately, studies typically fail to evaluate whether NSC replenishment in the fall occurs while $\mathrm{C}$-limitation is still in place, or after $\mathrm{C}$-limitation has ceased. If high NSC concentrations were attained during prevailing C-limitation, the question arises as to why these $\mathrm{C}$ reserves were not depleted to sustain other $\mathrm{C}$-sinks. This is particularly relevant given that $\mathrm{C}$-allocation to structural biomass accompanied by strong decreases of NSC reserves has been documented in broad-leaved tree seedlings grown under light exclusion (Weber et al. 2018).

Here, we define C-limitation as a situation where any plant performance improves when more $\mathrm{C}$ assimilates are provided. Exposure to shade reduces the $\mathrm{C}$-supply, and induces $\mathrm{C}$ efficient growth (increased etiolation, i.e. an increased shoot length per plant biomass, Berkowitz et al. 1995), which suggests that shaded plants face source C-limitation. In contrast, defoliation is an alternative method to induce C-limitation that might not only cause C-source limitation but also C-sink limitation, hindering the capacity to assign growth decreases to C source-limitation (Wiley et al. 2013, Schmid et al. 2017). Thus, any growth decrease under shade is likely caused directly by a limitation of C-assimilation.

Recent deep shade experiments showed substantial (about 30-60\%) decreases of NSC concentrations in temperate tree saplings, but also decreasing growth and survival (Veneklaas and den Ouden 2005, Piper et al. 2009, Maguire and Kobe 2015). However, nonexistent or low temporal resolution sampling in many shading studies makes it difficult to identify whether C-assimilation, storage or growth is the first critical factor to decline in such conditions. Thus, it is presently unclear if plants deplete their $\mathrm{C}$ reserves before growth decreases, or before death. In addition, reports on $\mathrm{C}$ assimilation, which could provide insights into the intensity of $\mathrm{C}$-limitation, are limited. If substantial $\mathrm{C}$ reserve pools were to be maintained during severe (almost lethal) C-limitation, they might be found most prominently in species that are adapted to low light environments. Maguire and Kobe (2015) found a correlation between shade tolerance (survival) and stored NSC in tree seedlings under shade. However, Piper et al. (2009) contradicted such a correlation, questioning the connection between NSC storage at low light and shade tolerance. Yet, growth rates under shaded conditions appear to depend on the species' shade tolerance, given that growth in shade tolerant species is more reduced at low light compared to shade intolerant species (Chen et al. 1996, Poorter 1999, Myers and Kitajima 2007, Imaji and Seiwa 2010). If the above-mentioned decreases in NSC concentrations at low light are quantified and compared 
to growth reductions, differences in the low-light $\mathrm{C}$ allocation patterns between shade tolerant and intolerant species might become quantifiable (Lusk and Piper 2007, Piper et al. 2009). However, previous studies that have investigated such allocation patterns have not standardized growth by the initial biomass, and thus could not provide relative reductions of growth in shade (i.e. a reduction of the relative growth rate; RGR).

At present, detailed insights are lacking into the dynamics of $\mathrm{C}$ reserves in non-lethally $\mathrm{C}$ limited trees over multi-year time periods. Such analyses could reveal if, and to which extent, $\mathrm{C}$ storage is maintained or rebuilt during C-limitation. In particular, they would show if Climited trees under shade reach NSC tissue concentrations of non-C-limited trees after an initial decrease of NSC levels, or, if new and lower steady state NSC concentrations are reached. The latter situation would allow trees to invest a relatively higher fraction of $\mathrm{C}$ assimilates into growth than the former scenario. To our knowledge, there are no studies available that have investigated the effect of deep shade on tree growth and NSC concentrations with sequential harvests over several seasons. Within a field experiment, we thus investigated the effect of permanent strong shading on growth and C-reserves of tree saplings over the course of three growing seasons. To cover a large spectrum of taxa, ten temperate tree species were used that included evergreen conifers and deciduous tree species, further differing in their adaptation to deep shade environments (Landolt et al. 2010).

Based on existing knowledge and the above-mentioned research goals, the following hypotheses were addressed:

1) As an initial effect of shading, all species exhibit decreasing NSC tissue concentrations immediately after the transfer to shade.

2) Shade intolerant, early successional species are "C-spenders" in shade. These species allocate significant amounts of assimilated $\mathrm{C}$ to growth even after years of severe shading, resulting in constantly and strongly reduced NSC reserves. Such reduced NSC concentrations are likely to make them more prone to other C-limiting events like defoliation by herbivory, eventually causing mortality.

This article is protected by copyright. All rights reserved. 
3) Shade tolerant, late successional species are "C-savers" in shade. These species maintain a high minimum C-reserve level, while growth remains low over time. NSC concentrations of such species might be less useful to infer a tree's $\mathrm{C}$ supply status, because they are largely influenced by a trade-off between storage and growth.

\section{Materials and Methods}

\section{Study site and experimental set-up}

The study was conducted between March 2015 and November 2017 in an open field about 10 $\mathrm{km}$ south-west of Basel, Switzerland (47 $\left.29^{\prime} 40^{\prime \prime} \mathrm{N}, 7^{\circ} 31^{\prime} 15^{\prime \prime} \mathrm{E}\right)$. The planting site for the experiment was former agricultural land. In March and April 2015, a total of 1020 three-yearold saplings from 10 common European forest tree species were purchased from a local nursery (Forstgarten Lobsingen, Switzerland). For this study we selected four evergreen conifer species (Abies alba MILL., Picea abies (L.) H.KARST, Pinus sylvestris L. and Pseudotsuga menziesii (MIRBEL) FRANCO) and six deciduous broadleaved tree species (Betula pendula ROTH, Carpinus betulus L., Fagus sylvatica L., Prunus avium L., Quercus petraea (MATTUSCHKA) LIEBL. and Tilia platyphyllos SCOP) that differed in their shade tolerance (Landolt et al. 2010; Table 1). Hereafter, all species will be referred to by their genus name only.

Due to scheduling constraints, 960 saplings were stored in a darkened $4^{\circ} \mathrm{C}$ storage room for 2-3 weeks after delivery before they could be planted. Six saplings of each species were harvested before planting and processed as described below to obtain initial biomass and NSC reserves. Remaining saplings were planted directly in the field into a loss-loamy soil mixed with smaller sized limestone rocks. In order to further improve soil quality, $5 \mathrm{~L}$ of universal soil (a mixture of compost, wood chaff and agricultural soil; $p H=7.5$ ) was added into the planting hole of each seedling during plantation. All deciduous trees were planted on March 30, 2015. Due to scheduling constraints and rainy and cool weather on the following dates, conifers were planted on April 20, 2015.

Saplings were planted in a total area of ca. $120 \mathrm{~m}^{2}$. Within this area, each of the ten species was planted in four separate plots (40 plots total), with each plot including 4 × $6=24$ saplings. The initial distance between saplings within one plot was $20 \mathrm{~cm}$, and the distance between plots was $60 \mathrm{~cm}$. Because saplings were continuously removed from the plots over the duration of the experiment, the space between the individual stems of the sapling 
increased over time. Border effects were neglected since $67 \%$ of the saplings were located on plot borders and the continuous removal of seedlings from the plots introduced changing light- and border-conditions within a plot.

To induce limitation on C-assimilation, a $3 \mathrm{~m}$ tall shading tunnel tent covered with fourlayers of a green plastic fiber shading net (Hortima AG, Hausen, Switzerland) was placed above half of the plots over a total area of $60 \mathrm{~m}^{2}$ (12 $\mathrm{m}$ length and $5 \mathrm{~m}$ width). To prevent lethal stress during the initial phase after transplantation, the shading was put in place about six weeks after planting on June 2, 2015. During the subsequent 30 months until November 20,2017 , shaded saplings were continuously exposed to $6 \%$ of ambient sun-light (overall mean PPFD $=13 \mu \mathrm{mol} \mathrm{m} \mathrm{m}^{-2} \mathrm{~s}^{-1}$ during daytime hours, Fig. S1). The un-shaded half of the trees (control) received full sunlight (overall daytime mean PPFD $=201 \mu \mathrm{mol} \mathrm{m} \mathrm{m}^{-2}$, Fig. S1). The mean daytime radiation during the growing season (April to October) was $29 \mu \mathrm{mol} \mathrm{m} \mathrm{m}^{-2}$ ${ }^{1}$ for shaded and $500 \mu \mathrm{mol} \mathrm{m} \mathrm{s}^{-1}$ for unshaded saplings. The red/far-red ratio was 1.0 above, and 0.7 below the shading tent (measured on an overcast summer day; SKR 100 red/far-red sensor, Skye Instruments Ltd, Powys, UK).

During the entire growing season of 2016, shaded broad-leaved species assimilated 84-97\% less $\mathrm{C}$ (depending on the species) than un-shaded controls, based on calculations using in situ measurements of PPFD and temperature combined with photosynthetic light response curves, specific leaf area and total leaf mass measurements (unpubl. data). In addition to the natural rainfall (645, 997 and $765 \mathrm{~mm} \mathrm{yr}^{-1}$ during 2015-2017; data provided by MeteoSwiss for a site $7 \mathrm{~km}$ north-east of the study site), plots were watered during dry periods to ensure sufficient water supply. Mean soil water potentials over the last two seasons at $20 \mathrm{~cm}$ soil depth were $0.07 \pm 0.04 \mathrm{MPa}$ in shade vs. $-0.08 \pm 0.02 \mathrm{MPa}$ in the control treatment $(n=5, \mathrm{MPS}-2$ sensors, Decagon, Pullman WA, USA). Mean annual soil temperature was $9.8^{\circ} \mathrm{C}$ vs. $11.7^{\circ} \mathrm{C}$ (MPS-2 sensors, Decagon, Pullman WA, USA) in shade and control plots, respectively, while mean annual air temperature was $10.3^{\circ} \mathrm{C}$ in shade vs. $10.8^{\circ} \mathrm{C}$ in the control plots and the annual mean relative air humidity was $87 \%$ vs. $85 \%$ (HOBO pro V2 sensors, Onset, Cape Cod MA, USA, Fig. S2).

This article is protected by copyright. All rights reserved. 


\section{Sampling and field measurements}

To quantify biomass increment and collect tissue samples for NSC analyses, 6 saplings per treatment and species were harvested each year in March (before bud break in spring), July (mid-season) and November (after leaf fall in autumn) except in 2017, when no saplings were harvested in July, due to the limited number of remaining trees. On each sampling date we aimed to collect a maximum amount of root tissue from sampled individuals without disturbing the neighboring remaining saplings. Therefore, roots from the top soil layer (about $20 \mathrm{~cm}$ ) were excavated around the stem prior to pulling the saplings from the ground.

However, in the last two seasons, some roots grew very deep, especially in the unshaded control plots, and had to be clipped at the lowest reachable soil depth. This resulted in an underestimation of the total root biomass in these cases. After harvest, roots were separated from aboveground biomass by clipping at the root collar, and all sampled sapling tissue was immediately sub-sampled into roots, stems, and leaves. Given the biased root mass in deep rooting saplings, we restricted detailed growth analyses to the aboveground tissues in all species.

All samples were oven-dried at $80^{\circ} \mathrm{C}$ for $72 \mathrm{~h}$, and aboveground dry biomass was weighed to quantify growth. For NSC analysis, a small subsample ( $\sim 1$ g dry mass) of stem wood (without bark), root wood (without bark) and leaves of each sapling was shock-heated in a microwave at $900 \mathrm{~W}$ twice for $15 \mathrm{~s}$ to stop enzymatic activity (Popp et al. 1996), and then oven-dried at $80^{\circ} \mathrm{C}$ for $72 \mathrm{~h}$. After measuring tissue dry biomass, all samples were ground to a fine homogenous powder with a horizontal ball-mill (MM 400, Retsch, Haan, Germany), and the powder was then stored in dark, dry conditions at room temperature until chemical analysis.

Because shoots tended to grow horizontally under shade in some species, the shoot length was measured as the distance between the root collar and the tip of the longest branch. The specific leaf area (SLA, $\mathrm{m}^{2} \mathrm{~kg}^{-1}$ ) for the six broad-leaved species was measured in August on four saplings from each light treatment. Round leaf stamps with $5 \mathrm{~mm}$ diameter were taken from three different leaves of each sapling, and immediately oven-dried at $80^{\circ} \mathrm{C}$ for $72 \mathrm{~h}$. Leaf flush was monitored in weekly intervals during 2016 and 2017 between March and June. The leaf fall dates were retrospectively estimated from photographs taken every two weeks between October and November 2017. 
NSC analyses

Non-structural carbohydrates (NSC) were analysed following a modified protocol by Wong (1990) and Hoch et al. (2002) as described in Weber et al. (2018). In detail, 8 - $12 \mathrm{mg}$ of dry plant powder was weighed into $6 \mathrm{ml}$ glass vials and water-soluble compounds were extracted with $2 \mathrm{ml}$ distilled water by boiling at $100^{\circ} \mathrm{C}$ for 30 minutes over steam. A $200 \mu \mathrm{l}$ aliquot was then treated with invertase from bakers yeast (Sigma-Aldrich, St. Louis, MO, USA) to degrade sucrose into glucose and fructose. $100 \mu \mathrm{l}$ of this extract was mixed with $100 \mu \mathrm{l}$ of a glucose-hexokinase assay (glucose-hexokinase assay reagent, Sigma Aldrich, St. Louis, MO, USA) thereby converting glucose to glucose-6-P and fructose to fructose-6-P. Isomerase (also from bakers yeast; Sigma-Aldrich, St. Louis, MO, USA) converted fructose-6-P to glucose-6-P. Due to the presence of NADP in the assay, all glucose-6-P was converted to gluconate-6-P and NADPH. Finally, the concentration of NADPH (equating to the concentration of glucose) was determined photometrically at $340 \mathrm{~nm}$ in a 96 -well micro plate photometer (HR 7000, Hamilton, Reno, NE, USA). $500 \mu 1$ of the original extract was treated with a fungal amyloglucosidase from Aspergillus niger (Sigma-Aldrich, St. Louis, MO, USA) in a $49^{\circ} \mathrm{C}$ water bath over night to break down starch to glucose. The total glucose content (corresponding to NSC) was then determined photometrically as described above. The concentration of starch was calculated by subtracting the low-molecular weight sugar concentrations from the total NSC value. To ensure activity of the enzymes, pure starch, and solutions of glucose, fructose and sucrose were used as standards. To control reproducibility of the extraction, standard plant powder (Orchard leaves, Leco, St. Joseph, MI, USA) was routinely analysed as a quality control. All NSC concentrations are given as \% dry matter.

\section{Additional defoliation treatment and mortality monitoring}

To investigate the effect of an additional C-limitation stress, $n=4$ control and shaded Carpinus were completely defoliated on June 5, 2017. At this date, Carpinus was the only species with all saplings surviving both light treatments (Fig. S3); and therefore, enough saplings remained to permit the additional defoliation treatment with only this species.

Regrowth after defoliation was monitored throughout the season and all defoliated trees were harvested in November 2017 as described above.

This article is protected by copyright. All rights reserved. 
Saplings were regularly visually monitored for mortality during each growing season. Mortality was assumed when no intact buds or leaves appeared on saplings between April and October. Ignoring the mortality directly following transplantation that was mainly observed in Pinus, mortality rates were calculated starting from March 2016 in each species and treatment, and given as the fraction of dead saplings among all planted saplings per species and treatment. In Summer 2016, especially high mortality occurred in shaded Fagus, most probably due to strong infestation by aphids (Phyllaphis fagi L.). Following this event, remaining Fagus saplings were treated with insecticide (Pyrethrine; Gesal, Compo, Allschwil, Switzerland) in the early season of 2017 to prevent additional losses by this mechanism.

\section{Calculations and statistics}

NSC tissue concentrations were compared between shaded and unshaded saplings separately for above and belowground tissues. Because needles are perennial tissues and important NSC storage pools in conifers, a weighted mean concentration of aboveground NSC concentrations were calculated for each conifer sapling by integrating tissue mass and NSC concentrations as described in Hoch et al. (2002), using the following formula:

$$
\sum_{t i s s=1}^{n} \frac{\text { oonc }_{\text {tiss }} \mathrm{x} \text { biom }_{\text {tiss }}}{100}
$$

where $n$ is the number of tissues, conc $_{t i s s}$ is the tissue specific NSC concentration (\% dry matter) and biom $_{\text {tiss }}$ is the tissue specific fraction of the total biomass. For deciduous broadleaved species, only NSC concentrations of stem wood were used for the comparison of NSC concentrations in aboveground tree tissues, since leaves are only present during the season and are not a perennial storage pool.

Because the strongest shoot growth occurred in May and June, we pooled aboveground biomass measurements from July, November from one year and from the subsequent March of the following year to calculate the biomass after the main seasonal growth (between April and June) for each species. The annual relative growth rate (aboveground RGR, $\mathrm{g} \mathrm{g}^{-1} \mathrm{yr}^{-1}$ ) was calculated by dividing the mean biomass after each growing season by the mean biomass before the growing season. Because leaves were present only in the July harvests in 
deciduous species, leaves were not included in aboveground RGR calculations of deciduous trees to enable the comparability of biomass measurements between seasons. The standard error (SE) of the aboveground RGR in each growing season (as shown in Fig. 2, see later) was propagated from the SE of absolute dry biomass before and after each growing season, using a general formula for error propagation in ratios (Geary 1930).

To investigate the trajectory of growth versus NSC production in reaction to shade, we compared the annual aboveground RGR with the November mean sapling NSC concentrations among each species and season. NSC values from March and July were omitted for this trajectory, since NSC concentrations likely show maximum variation during summer in deciduous broad-leaved species, and during spring in evergreen conifers.

Significant differences between light treatments on growth and NSC concentrations at specific harvest dates were determined by Student's $t$-tests. To test the effect of shading on growth, we performed a full-factorial ANOVA with harvest season and light treatment as fixed factors (biomass $\sim$ season + treatment) for each species. To test NSC concentration changes over winter, we performed individual two-factorial ANOVA tests with sampling season (autumn or spring) and shading year (2015 or 2016) as fixed factors (NSC sampling season + shading year). To test whether any growth occurred under shade, we performed a full-factorial ANOVA exclusively on shaded saplings with harvest season and species as fixed factors (biomass $\sim$ season + species). The influence of light treatment on seasonal variations in NSC concentrations was tested for significance for every species with a twofactorial ANOVA with treatment, harvest date and their interaction as factors (NSC treatment * date). Biomass and NSC concentrations in Carpinus were tested for significant differences $(\alpha=0.05)$ among defoliation and light treatments with a Tukey's Honest Significant Difference (HSD) test. The R software package (3.3.2) was used for all statistical analysis.

\section{Results}

Phenology and survival

Leaves and needles of shaded saplings were darker green, and were more horizontally oriented compared to unshaded controls of all species (Fig. S4). Mean SLA in broadleaved species was 134-198\% higher (depending on the species) in shade across all three seasons ( $\mathrm{t}-$ test, $p<0.001, n=4)$. In most broadleaved species, leaf bud break and unfolding in spring 
2016 and 2017 was advanced in shade, except for Betula, where leaf unfolding in shaded saplings was delayed by $c$. three weeks compared to controls (Fig. S5). Except for Picea saplings that showed a significant delay of bud break by c. 3 weeks in shade compared to controls in spring 2016, there was no significant effect of shading on leaf phenology in conifers (Fig. S5). Leaf fall from deciduous species in autumn was delayed by approximately one week under shade compared to controls in most species, and over four weeks in shaded Prunus and Tilia (rough estimations from photographs taken every two weeks). Mortality occurred in shade during the first shading season (2015) in Pinus and Pseudotsuga, and no Pinus sapling in shade survived the winter 2015/2016. In 2016, mortality was high in shaded Pseudotsuga, Fagus, Tilia and Betula (25-61\%; Fig. S3). In 2017, mortality was only observed in Betula under shade.

\section{Growth}

Due to the later start of shading in 2015, the aboveground biomass increment over the entire season was not significantly different between controls and shaded saplings (Fig. 1). In 2016 and 2017, aboveground wood biomass increased exponentially in control saplings. After June 2016, biomass in controls was significantly different from shaded individuals in all species, except for Pseudotsuga and Tilia (Fig. 1). After June 2017, biomass in controls was significantly different from shaded saplings in all species (Fig. 1). During 2017, biomass increased moderately but significantly in all species in shade (two-factorial ANOVA, $p<$ $0.01)$.

In 2015, the aboveground RGR in controls and shaded saplings was $c .1 \mathrm{~g} \mathrm{~g}^{-1} \mathrm{yr}^{-1}$, but increased in 2016 and 2017 to values between 1 and $4 \mathrm{~g} \mathrm{~g}^{-1} \mathrm{yr}^{-1}$ in controls of most species, except in Abies, where the aboveground RGR in controls remained very low c. $0.5 \mathrm{~g} \mathrm{~g}^{-1} \mathrm{yr}^{-1}$ (Fig. 2). In shaded saplings, the aboveground RGR remained at or below $1 \mathrm{~g} \mathrm{~g}^{-1} \mathrm{yr}^{-1}$ in all species throughout the three seasons. Broad-leaved species had 0-38\% less leaf dry mass per individual in shade compared to controls in July 2015, and 57-93\% less in July 2016 (data not shown). Shoot length did not differ between light treatments in 2015, but was significantly lower in shaded compared to control saplings in Fagus and Betula by the end of the second growing season (Fig. S6). At the end of the experiment in autumn 2017, only Prunus and Tilia had similar shoot length in both light treatments ( $t$-test, $p>0.05)$, while in the remaining species shoot length was $22-50 \%$ lower in shaded compared to control saplings (Fig. S6). Probably also caused by the lower red/far-red ratio under the shading net $(\mathrm{r} / \mathrm{fr}=$ 
0.7), the etiolation (shoot length per shoot biomass) was significantly increased under shade by $71 \%$ (Abies) to $450 \%$ (Carpinus) in November 2017 ( $t$-test, $p>0.05$ ) in all species.

There were no significant differences in the root : shoot ratio between shaded and control saplings in all species by the end of the first season in 2015. However, despite the incomplete root harvest in some control saplings (see Materials and Methods), the root : shoot ratio of all species increased in unshaded controls compared to shaded saplings in the following seasons (data not shown). By the end of 2017, the root : shoot ratios were significantly higher in the control saplings ( $t$-test, $\mathrm{p}<0.05$ ) of Abies, Picea, Carpinus and Fagus, with Abies showing the highest difference ( 0.71 in controls vs. 0.31 in shaded saplings).

\section{Non-structural carbohydrates}

Across all species, NSC concentrations in all tissues from shaded saplings were about $50 \%$ lower than control values in the first year, but approached values of unshaded control saplings during the second year, and completely recovered to control values by the end of third season (Fig. 3, 4). Although we observed lower soluble sugar and starch concentrations in stem wood than in leaves and roots (Fig. S7-S12), the observed temporal trend of total NSC was similar among all tissues (Fig. 3, 4).

In most deciduous species, NSC concentrations remained unchanged between March and July 2015 in controls, but declined in shade (Fig. 3, 4). Betula was the exception, with NSC concentration increases during the first half of the 2015 season in shaded saplings, and even larger increases in controls (Fig. 3, 4). NSC concentrations did not recover in shade by November of the first season (Fig. 3, 4). By November 2016, NSC concentrations in stems did not differ significantly between shaded and control deciduous saplings, except for Fagus (which was likely weakened by a strong aphid infestation under shade; Fig. 3), while NSC concentrations in roots were still significantly lower in Betula, Carpinus and Fagus (Fig. 4). By the end of the experiment in November 2017, NSC concentrations in stems and roots were not significantly different anymore between shaded and control saplings in all broadleaved species (Fig. 3, 4). 
In all four investigated conifer species, NSC levels declined between March and July in shaded and control saplings during the first season (2015), but increased again until November in both light treatments (Fig. 3, 4). While the NSC concentrations in November 2015 were similar or higher than those measured in March 2015 in controls, they were significantly lower in shaded saplings, both in the aboveground tissues and roots (Fig. 3, 4). Especially low NSC concentrations were found in shaded Pinus, which also showed complete mortality in shade by the end of the first season (Fig. S3), and NSC concentrations were consequently not measured anymore after 2015 in Pinus. By November 2016, NSC concentrations in shaded conifers were still generally lower than controls (Fig. 3, 4). By the end of the experiment in November 2017, NSC concentrations in shaded saplings had reached control levels in most species and tissues (Fig. 3, 4), but root wood NSC concentrations were still significantly lower in shaded Abies and Picea (Fig. 3, 4).

In all investigated broad-leaved and conifer species, NSC concentrations in stem wood were 23-62\% lower than in root wood (Fig. S7, S8, S10, S11). NSC in leaves of broad-leaved species contributed $8-34 \%$, and in conifer needles $63-86 \%$ to the aboveground sapling NSC pool (species averages; Fig. S7, S9, S10, S12). Although starch showed stronger concentration fluctuations than soluble sugars, recovery towards 2017 was observed in both compounds (Fig. S7-S12).

\section{Additional defoliation treatment and herbivory}

In 2017, we performed an additional defoliation treatment on Carpinus saplings. All defoliated saplings produced new leaves within two weeks after defoliation except one defoliated, shaded sapling, which died after defoliation without having flushed new leaves. NSC concentrations in defoliated Carpinus saplings recovered completely to the levels of undefoliated saplings by November in unshaded saplings. In contrast, NSC concentrations in November were severely depleted in defoliated saplings from the shading treatment $(0.8 \%$ and 1.0\% DM in stem and root wood, respectively; Fig. 5). In stem wood of defoliated, shaded saplings, starch concentrations were almost $100 \%$, and sugars $80 \%$, lower compared to non-defoliated saplings at full sunlight. Starch and sugars in root wood were decreased by $98 \%$ and $87 \%$, respectively (data not shown).

This article is protected by copyright. All rights reserved. 
Although NSC concentrations were not measured in dead individuals during the three-year shading treatment, mortality primarily occurred when NSC concentrations of the surviving individuals from the same treatment and species were also low, like in shaded Pinus in November 2015 (Fig. 3, 4), or in shaded and herbivore-stressed Fagus in July 2016 (Fig. 3, 4). However, we observed no mortality in shaded Abies and Picea, despite unusually low needle NSC concentrations of 2.3\% DM and 2.5\% DM, respectively, in July 2015 (Fig. S9, S12).

\section{Growth vs. NSC under long-term C-limitation}

A comparison of November NSC concentrations with the aboveground RGR in each growing season yielded a similar trajectory of growth versus storage in all species (Fig. 6). While the complete refilling of NSC stores to $100 \%$ of control concentrations was achieved by most species by the end of the third season ("2" in Fig. 6 and 7), the annual aboveground RGR remained at $c .30 \%$ of controls among all species (Fig. 6, 7). Across all species, the relatively late start of shading in the middle of the "acclimation season" 2015 (marked as "0" in Fig. 6, 7), caused annual aboveground RGR in shade to be as high as in controls, which possibly hindered recovery of NSC concentrations by fall after the start of shading. Overall, the observed patterns did not correspond to the species' light adaptations (Table 1), since light adapted, early successional species did not show more growth or less NSC under shade than shade adapted, late successional species (Fig. 6).

\section{Discussion}

The data from this study clearly demonstrate that growth was reduced in long-term C-limited tree saplings, although during this period NSC concentrations were maintained at non-zero levels. The data also show that after two full seasons, the NSC concentrations were almost equal between both applied light treatments. Future studies using NSC values of temperate species as an indicator for C-limitation should thus be aware that substantially elevated NSC tissue concentrations can also occur during C-limitation. However, we demonstrated that a recent onset of C-limitation is reflected in decreased NSC levels, and life-threatening Climitation induces a depletion of $\mathrm{C}$ reserves to less than $\sim 20 \%$ of controls. We conclude that lethal C-starvation can be predicted more easily from NSC concentrations, than non-lethal Climitation. $\mathrm{C}$ allocation patterns (storage vs. growth) under shade did not correlate with species-specific shade tolerance, which suggests more complex mechanisms behind shade tolerance.

This article is protected by copyright. All rights reserved. 
The seasonal fluctuations of NSC concentrations in conifers from both light treatments found in this study are in broad agreement with previous reports (Hoch et al. 2003, Bansal and Germino 2008). However, the inconsistent fluctuations of NSC concentrations during summer between both light treatments in broad-leaved species indicates that $6 \%$ light not only caused an initial decrease in NSC concentrations, but might have also altered the seasonal NSC dynamics.

Consistent with previous deep-shade experiments (Veneklaas and den Ouden 2005, Piper et al. 2009, Maguire and Kobe 2015) and with our first hypothesis, we found a two-fold decrease of NSC concentrations after the first shading season. The complete recovery of NSC concentrations to control levels after three seasons contradicts our second and third hypothesis, but corresponds to findings in a tropical forest, where NSC concentrations even decreased with increasing light availability in naturally grown saplings (Poorter and Kitajima 2007). The same study by Poorter and Kitajima (2007) highlighted the importance of NSC reserves under shaded conditions. In contrast to that study, we did not find significantly increased NSC concentrations in shade-grown saplings. NSC concentrations therefore did not correlate with the species' shade tolerance (Table 1), which was also not the case in other shading studies (Lusk and Piper 2007, Piper et al. 2009). For example, we found the lowest overall NSC concentrations at low light in shade-tolerant Abies and Picea, despite a complete absence of mortality under shade in these species. Moreover, at the end of the experiment, Abies and Picea were the only species that still showed significantly lower NSC concentrations in shade compared to controls. In contrast to Kobe (1997), who suggested a strong relationship of root NSC concentrations and survival in deciduous and evergreen temperate tree species, our data suggests that survival in shade depends on more factors than stored NSC pools alone. Unlike Kobe et al. (1995), we found no correlation between lowlight survival and growth rate at high light, since we observed especially high survival rates at low light in fast-growing species like Carpinus and Picea. The 6\% of full sunlight applied in this experiment compares well to the $5-7 \%$ of above-canopy radiation that is on average found in the understory of mixed temperate forests (Messier et al. 1998), and it is slightly lower than the 7-13\% reported for a boreal birch forest (Messier et al. 1998). Therefore, even more severe light restriction experiments may be required to draw further conclusions about shade tolerance. 
The saplings used in this study were planted directly in the soil, and it was not possible to harvest the entire root system from some large trees. For that reason, we focused our growth analyses on aboveground tissue. The analyses of aboveground biomass production revealed low and unchanged RGRs over time in all shaded trees, while RGR increased strongly in most species under unshaded conditions. However, if shaded trees would have allocated substantially more new biomass to roots than the unshaded control plants, total biomass RGR might have been more similar in both light treatments. Still, a higher proportional root biomass under shade can be excluded, since the root/shoot ratio was found to be lower under shade in 2016 and 2017, despite the harvest of an unquantified root biomass fraction in some of the unshaded control trees (i.e., roots could be harvested completely form shaded saplings, while in some unshaded controls, very deep reaching roots had to be left in the soil at harvest). In addition, previous studies reported exclusively a decrease of the root : shoot ratio under shade (Dias-Filho 2000, Schall et al. 2012). This indicates, that in our study, the total biomass RGR was probably even more reduced under shade compared to full sunlight, than suggested from the analyses on the aboveground biomass alone.

\section{C-allocation under C-limitation}

To roughly estimate the effect of shading on the total annual net $\mathrm{C}$-assimilation of the saplings, we performed a simple model for the 6 broad-leaved species, based on light response curves of photosynthesis and in-situ measurements of light and temperature as well as total leaf area per sapling (unpubl. data). This model indicated that the seasonal net $\mathrm{C}$ assimilation of shaded saplings was likely less than $15 \%$ of the unshaded controls. It therefore can be assumed that the productivity of the shaded saplings was significantly limited by their severely restricted C supply. C-limitation of growth under shade has been shown previously in liana species, which exhibited significantly stronger relative growth increases at elevated atmospheric $\mathrm{CO}_{2}$ concentrations under low light compared to high light conditions (Granados and Körner 2002). Across the three seasons observed in the current study, the limited C-supply under shade obviously restricted growth, while at the same time, the tissue NSC concentrations were rebuilt and maintained (Fig. 7).

One possible explanation for this finding is that under shade, $\mathrm{C}$-storage activities are retained at the expense of structural growth. Although we did not investigate other $\mathrm{C}$ reserve compounds here (e.g., storage lipids), we suggest that our results justify this notion, since NSC are quantitatively the most important $\mathrm{C}$ storage compounds for all of the investigated 
species (Hoch et al. 2003). Our findings thus seem to support the assumption of Wiley and Helliker (2012) that trees might favor C reserve formation over growth at C-limitation. However, our results do not necessarily support the second assumption by Wiley and Helliker (2012), that C-limitation can actually lead to higher NSC pools compared with sufficiently C supplied trees. In addition, such a concept implies a 'strategic decision' of a tree to reduce growth in order to save $\mathrm{C}$ for storage, or to prioritize processes related to $\mathrm{C}$ storage leaving less $\mathrm{C}$ for structural growth, which might be misleading. In fact, what might look like a central prioritization of one process, is likely the net-result of the activity of many individual processes driven by the local conditions within different organs and tissues of a plant.

The actual cause of decreased growth under deep shade remains unclear. For example, reduced growth activity can be directly induced by light signals like low PAR or decreased red/far-red ratio (Ballaré and Casal 2000); or growth might decline in response to a declining need for new xylem vessels under shade due to a reduction of total leaf area (Schmid et al. 2017). To resolve the question of whether tree growth can indeed decrease in response to an up-regulation of C-storage, the usage of knock-out mutants for C-storage may be informative, similar to studies on the diurnal C-storage regulation in Arabidopsis (Gibon et al. 2004, Rolland et al. 2006, Smith and Stitt 2007, Gibon et al. 2009, Sulpice et al. 2009). Whatever the physiological reasons for the growth and NSC dynamics in tree saplings under shade observed here, the net result after three growing seasons are saplings with severely reduced growth, but tissue NSC reserves that are on par with unshaded saplings.

In contrast to the maintenance of NSC levels and restriction of growth in shaded saplings, we observed a reversal of $\mathrm{C}$ allocation in shaded Carpinus saplings that received an additional defoliation treatment. Defoliation caused saplings to invest most of the available NSC reserves into leaf production, although the resulting $\mathrm{C}$ assimilation for the rest of the season in shaded saplings seems to have gained only $4 \%$ of the NSC concentrations in un-shaded saplings (Fig. 5). Therefore, NSC concentrations lower than approximately $20 \%$ compared to those in controls indicated a life-threatening C-limitation in this case.

\section{Usage of NSC concentrations to predict C-limitation}

In deciduous species, NSC concentrations in above- and belowground tissues tended to be more depleted during summer under shade compared to controls. For example, we observed a strong depletion of stem wood NSC in shaded Prunus in July 2016, despite similar NSC

This article is protected by copyright. All rights reserved. 
reserves in shade and controls in the precedent and subsequent winter (Fig. 3, 4). Such depletion indicates that leaf flush in spring induced a longer-lasting depletion of NSC under shade, than at ambient light, and additional C-limiting factors (e.g. herbivory) might additionally intensify such depletion. We thus suggest, that the likelihood of reduced NSC pools in summer is higher in deciduous species. Detection of present C-limitation in deciduous species is therefore more probable when NSC concentrations are assessed a few weeks after leaf flush. In the investigated evergreen species, such a "detection time-frame" was not observed, probably because evergreens have the ability to assimilate $\mathrm{C}$ during winter and early spring before the next leaf flush, and thus, do not exclusively rely on stored NSC reserves to flush (Bonan and Sirois 1992, Hoch et al. 2003, Holst et al. 2008).

In conclusion, our findings emphasize that measurements of tissue NSC concentrations should be used very cautiously in order to assess the $\mathrm{C}$ supply status of trees. Certainly, such assessments always require the comparative measurements of NSC concentrations in potentially $\mathrm{C}$-limited and not $\mathrm{C}$-limited control trees. Our findings further highlight the necessity to account for the seasonal dynamics of NSC pools, instead of comparing a single date in order to predict the absence or presence of C-limitation in trees. Whether these results gained from young tree saplings also apply to mature forest trees is currently unclear. The generally larger NSC pools of adult, tall trees suggests that survival during C-starvation would probably not require as high NSC tissue concentrations as those observed in small saplings in this study.

\section{Acknowledgements}

We would like to thank Sandra Schmid, Dr. Urs Weber, Svenja Förster, Fabienne Nick, Till Buser and Kai Reinacher for help during fieldwork. We also thank Prof. Nikolaus Kuhn (University of Basel) for access to their infrastructure at the study site, and Dr. Stefan Kimmel (IES Ltd.) for providing the shading tent scaffolds. Additionally, we thank Prof. Simon M. Landhäusser (University of Alberta, Canada) for suggesting the additional defoliation experiment. We thank Dr. Daniel B. Nelson for editing the text. This research was funded by the Swiss National Science Foundation project 'MinCarbRes' (no. 31003A 156944/1 to G.H.)

This article is protected by copyright. All rights reserved. 


\section{Authors contribution}

G.H. and A.G. planned and designed the research. R.W. Conducted the experiments, analyzed the data and wrote the first draft of the manuscript. All authors contributed to the final version of the manuscript.

\section{References}

Ballaré, C. L. and J. J. Casal. 2000. Light signals perceived by crop and weed plants. Field Crops Research 67:149-160.

Bansal, S. and M. Germino. 2008. Carbon balance of conifer seedlings at timberline: relative changes in uptake, storage, and utilization. Oecologia 158:217.

Berkowitz, A. R., C. D. Canham, and V. R. Kelly. 1995. Competition vs. facilitation of tree seedling growth and survival in early successional communities. Ecology 76:11561168.

Bonan, G. B. and L. Sirois. 1992. Air temperature, tree growth, and the northern and southern range limits to Picea mariana. Journal of Vegetation Science 3:495-506.

Chen, H. Y., K. Klinka, and G. J. Kayahara. 1996. Effects of light on growth, crown architecture, and specific leaf area for naturally established Pinus contorta var. latifolia and Pseudotsuga menziesii var. glauca saplings. Canadian Journal of Forest Research 26:1149-1157.

Dias-Filho, M. B. 2000. Growth and biomass allocation of the C4 grasses Brachiaria brizantha and B. humidicola under shade. Pesquisa Agropecuária Brasileira 35:23352341.

Galiano, L., G. Timofeeva, M. Saurer, R. Siegwolf, J. Martínez - Vilalta, R. Hommel, and A. Gessler. 2017. The fate of recently fixed carbon after drought release: towards unravelling $\mathrm{C}$ storage regulation in Tilia platyphyllos and Pinus sylvestris. Plant, Cell \& Environment 40:1711-1724.

Geary, R. C. 1930. The frequency distribution of the quotient of two normal variates. Journal of the Royal Statistical Society 93:442-446.

Gibon, Y., O. E. Bläsing, N. Palacios - Rojas, D. Pankovic, J. H. Hendriks, J. Fisahn, M. Höhne, M. Günther, and M. Stitt. 2004. Adjustment of diurnal starch turnover to short days: depletion of sugar during the night leads to a temporary inhibition of carbohydrate utilization, accumulation of sugars and post - translational activation of ADP - glucose pyrophosphorylase in the following light period. The Plant Journal 39:847-862.

Gibon, Y., E. T. PYL, R. Sulpice, J. E. Lunn, M. Hoehne, M. Guenther, and M. Stitt. 2009. Adjustment of growth, starch turnover, protein content and central metabolism to a decrease of the carbon supply when Arabidopsis is grown in very short photoperiods. Plant, Cell \& Environment 32:859-874.

Granados, J. and C. Körner. 2002. In deep shade, elevated $\mathrm{CO}_{2}$ increases the vigor of tropical climbing plants. Global Change Biology 8:1109-1117.

Hoch, G. 2015. Carbon reserves as indicators for carbon limitation in trees. Pages 321-346 in U. Lüttge and W. Beyschlag, editors. Progress in Botany. Springer, Heidelberg, Germany.

This article is protected by copyright. All rights reserved. 
Hoch, G., M. Popp, and C. Körner. 2002. Altitudinal increase of mobile carbon pools in Pinus cembra suggests sink limitation of growth at the Swiss treeline. Oikos 98:361374.

Hoch, G., A. Richter, and C. Körner. 2003. Non - structural carbon compounds in temperate forest trees. Plant, Cell \& Environment 26:1067-1081.

Holst, J., R. Barnard, E. Brandes, N. Buchmann, A. Gessler, and L. Jaeger. 2008. Impacts of summer water limitation on the carbon balance of a Scots pine forest in the southern upper Rhine plain. Agricultural and Forest Meteorology 148:1815-1826.

Imaji, A. and K. Seiwa. 2010. Carbon allocation to defense, storage, and growth in seedlings of two temperate broad-leaved tree species. Oecologia 162:273-281.

Kobe, R. K. 1997. Carbohydrate allocation to storage as a basis of interspecific variation in sapling survivorship and growth. Oikos:226-233.

Kobe, R. K., S. W. Pacala, J. A. Silander, and C. D. Canham. 1995. Juvenile tree survivorship as a component of shade tolerance. Ecological Applications 5:517-532.

Körner, C. 2003. Carbon limitation in trees. Journal of Ecology 91:4-17.

Lacointe, A., E. Deleens, T. Ameglio, B. Saint - joanis, C. Lelarge, M. Vandame, G. Song, and F. Daudet. 2004. Testing the branch autonomy theory: a ${ }^{13} \mathrm{C} /{ }^{14} \mathrm{C}$ double labelling experiment on differentially shaded branches. Plant, Cell \& Environment 27:1159-1168.

Landolt, E., B. Bäumler, A. Erhardt, O. Hegg, F. Klötzli, W. Lämmler, M. Nobis, K. Rudmann-Maurer, F. Schweingruber, and J.-P. Theurillat. 2010. Flora indicativa $=$ Ecological indicator values and biological attributes of the flora of Switzerland and the Alps: ökologische Zeigerwerte und biologische Kennzeichen zur Flora der Schweiz und der Alpen. Haupt Verlag, Bern.

Lusk, C. and F. I. Piper. 2007. Seedling size influences relationships of shade tolerance with carbohydrate - storage patterns in a temperate rainforest. Functional Ecology 21:7886.

Maguire, A. J. and R. K. Kobe. 2015. Drought and shade deplete nonstructural carbohydrate reserves in seedlings of five temperate tree species. Ecology and evolution 5:57115721.

Messier, C., S. Parent, and Y. Bergeron. 1998. Effects of overstory and understory vegetation on the understory light environment in mixed boreal forests. Journal of Vegetation Science 9:511-520.

Myers, J. A. and K. Kitajima. 2007. Carbohydrate storage enhances seedling shade and stress tolerance in a neotropical forest. Journal of Ecology 95:383-395.

Olson, J. S., J. A. Watts, and L. J. Allison. 1983. Carbon in live vegetation of major world ecosystems. Oak Ridge National Lab., TN (USA).

Palacio, S., R. Hernández, M. Maestro-Martínez, and J. J. Camarero. 2012. Fast replenishment of initial carbon stores after defoliation by the pine processionary moth and its relationship to the re-growth ability of trees. Trees 26:1627-1640.

Palacio, S., A. Hester, M. Maestro, and P. Millard. 2008. Browsed Betula pubescens trees are not carbon - limited. Functional Ecology 22:808-815.

Palacio, S., G. Hoch, A. Sala, C. Körner, and P. Millard. 2014. Does carbon storage limit tree growth? New Phytologist 201:1096-1100.

Piper, F., M. Reyes-Díaz, L. Corcuera, and C. Lusk. 2009. Carbohydrate storage, survival, and growth of two evergreen Nothofagus species in two contrasting light environments. Ecological research 24:1233-1241.

This article is protected by copyright. All rights reserved. 
Poorter, L. 1999. Growth responses of 15 rain - forest tree species to a light gradient: the relative importance of morphological and physiological traits. Functional Ecology 13:396-410.

Poorter, L. and K. Kitajima. 2007. Carbohydrate storage and light requirements of tropical moist and dry forest tree species. Ecology 88:1000-1011.

Popp, M., W. Lied, A. J. Meyer, A. Richter, P. Schiller, and H. Schwitte. 1996. Sample preservation for determination of organic compounds: microwave versus freezedrying. Journal of Experimental Botany 47:1469-1473.

Rolland, F., E. Baena-Gonzalez, and J. Sheen. 2006. Sugar sensing and signaling in plants: conserved and novel mechanisms. Annu. Rev. Plant Biol. 57:675-709.

Sala, A., W. Fouts, and G. Hoch. 2011. Carbon storage in trees: does relative carbon supply decrease with tree size? Pages 287-306 in F. C. Meinzer, B. Lachenbruch, and T. E. Dawson, editors. Size-and age-related changes in tree structure and function. Springer, Heidelberg, Germany.

Schall, P., C. Lödige, M. Beck, and C. Ammer. 2012. Biomass allocation to roots and shoots is more sensitive to shade and drought in European beech than in Norway spruce seedlings. Forest ecology and management 266:246-253.

Schmid, S., S. Palacio, and G. Hoch. 2017. Growth reduction after defoliation is independent of $\mathrm{CO}_{2}$ supply in deciduous and evergreen young oaks. New Phytologist 214:14791490.

Smith, A. M. and M. Stitt. 2007. Coordination of carbon supply and plant growth. Plant, Cell \& Environment 30:1126-1149.

Sulpice, R., E.-T. Pyl, H. Ishihara, S. Trenkamp, M. Steinfath, H. Witucka-Wall, Y. Gibon, B. Usadel, F. Poree, and M. C. Piques. 2009. Starch as a major integrator in the regulation of plant growth. Proceedings of the national academy of sciences 106:10348-10353.

Veneklaas, E. J. and F. den Ouden. 2005. Dynamics of non-structural carbohydrates in two Ficus species after transfer to deep shade. Environmental and Experimental Botany 54:148-154.

Weber, R., A. Schwendener, S. Schmid, S. Lambert, E. Wiley, S. M. Landhäusser, H. Hartmann, and G. Hoch. 2018. Living on next to nothing: tree seedlings can survive weeks with very low carbohydrate concentrations. New Phytologist 218:107-118.

Wiley, E. and B. Helliker. 2012. A re - evaluation of carbon storage in trees lends greater support for carbon limitation to growth. New Phytologist 195:285-289.

Wiley, E., S. Huepenbecker, B. B. Casper, and B. R. Helliker. 2013. The effects of defoliation on carbon allocation: can carbon limitation reduce growth in favour of storage? Tree Physiology 33:1216-1228.

Wong, S. 1990. Elevated atmospheric partial pressure of $\mathrm{CO}_{2}$ and plant growth. Oecologia 44:68-74.

Würth, M. K., S. Pelaez-Riedl, S. J. Wright, and C. Körner. 2005. Non-structural carbohydrate pools in a tropical forest. Oecologia 143:11-24.

This article is protected by copyright. All rights reserved. 


\section{Supporting Information}

Fig. S1 Histogram of daylight measurements.

Fig. S2 Fluctuations of daily air temperatures.

Fig. S3 Sapling mortality.

Fig. S4 Photographs of saplings.

Fig. S5 Leaf flush observations.

Fig. S6 Aboveground shoot length.

Fig. S7 Time course of sugars in stem wood.

Fig. S8 Time course of sugars in root wood.

Fig. S9 Time course of sugars in leaves and needles.

Fig. S10 Time course of starch in stem wood.

Fig. S11 Time course of starch in root wood.

Fig. S12 Time course of starch in leaves and needles.

Table 1 List of investigated species, separated by functional groups and light levels, to which seedlings of the respective species are adapted to $(1=$ strong shade; $2=$ intermediate shade; 3 = weak shade; 4 = bright light; Landolt et al., 2010).

\begin{tabular}{|c|c|c|}
\hline Species & Functional group & $\begin{array}{l}\text { Light } \\
\text { adaptation }\end{array}$ \\
\hline Abies alba & Evergreen conifer & 1 \\
\hline Picea abies & Evergreen conifer & 1 \\
\hline Pinus sylvestris & Evergreen conifer & 4 \\
\hline Pseudotsuga menziesii & Evergreen conifer & 2 \\
\hline Betula pendula & $\begin{array}{l}\text { Deciduous broad- } \\
\text { leaved }\end{array}$ & 4 \\
\hline Carpinus betulus & $\begin{array}{l}\text { Deciduous broad- } \\
\text { leaved }\end{array}$ & 2 \\
\hline Fagus sylvatica & $\begin{array}{l}\text { Deciduous broad- } \\
\text { leaved }\end{array}$ & 1 \\
\hline Prunus avium & $\begin{array}{l}\text { Deciduous broad- } \\
\text { leaved }\end{array}$ & 3 \\
\hline Quercus petraea & $\begin{array}{l}\text { Deciduous broad- } \\
\text { leaved }\end{array}$ & 3 \\
\hline Tilia platyphyllos & $\begin{array}{l}\text { Deciduous broad- } \\
\text { leaved }\end{array}$ & 2 \\
\hline
\end{tabular}

This article is protected by copyright. All rights reserved. 
Fig. 1 Aboveground dry biomass in the investigated 10 tree species (without leaves in deciduous species) at 100\% sunlight (open circles) and at 6\% light (closed circles) over three years (means $\pm \mathrm{SE}, n=6$ ). Asterisks above open circles indicate significant differences between controls and shaded individuals at a given harvest date $(t$-test, $P<0.05)$.

Fig. 2 Aboveground relative growth rate (RGR) in the investigated 10 tree species as described in the Materials and Methods section. Data from July, November and subsequent March after each annual growth in spring were pooled (propagated means $\pm \mathrm{SE}, n=18$ ).

Fig. 3 Time series of aboveground nonstructural carbohydrate (NSC) concentrations in the investigated 10 tree species at 100\% light (open circles) and 6\% light (closed circles) between March 2015 and November 2017. NSC concentrations in conifers are given as the mean $( \pm S E)$ of the weighted concentrations per dry matter of needles and stem wood as described in the Materials and Methods section $(n=6)$. NSC concentrations of deciduous species are only shown for stem wood, since leaves were present only in summer. Mortality events with over six fatalities per treatment are marked with black arrows. Asterisks above open circles indicate significant differences between controls and shaded individuals at a given harvest date $(t$-test, $P<0.05)$.

Fig. 4 Time series of nonstructural carbohydrate concentrations (NSC; means \pm SE) in root wood of the investigated 10 tree species at 100\% light (open circles) and 6\% light (closed circles) between March 2015 and November 2017. Asterisks above open circles indicate significant differences between controls and shaded individuals at a given harvest date ( $t$-test, $P<0.05)$.

Fig. 5 (a) Aboveground dry biomass (means \pm SE) and (b) nonstructural carbohydrates (NSC, means \pm SE) in stem and root wood of Carpinus betulus in November 2017, 5 months after defoliation at different light levels. Different letters indicate significant differences (comparable only within biomass, and for NSC concentrations within each tissue, only; Tukey's HSD, $P<0.05, n=4-6)$.

Fig. 6 Comparison of aboveground NSC storage and aboveground growth in nine species in all three seasons (2015 to 2017). The shade : control ratio of weighted aboveground NSC concentrations in November (stem wood in broadleaved, stem wood and needles in conifers; 
$x$-axis, propagated means, $n=6$ ) are plotted against the shade : control ratio of the annual aboveground dry matter RGR ( $y$-axis, propagated means, $n=18$, see the Materials and Methods section) for each species. C, unshaded controls; 0, shaded individuals during 2015 ('acclimation season', where shading started after shoot growth); 1, shaded individuals during 2016 (first full shading season); 2, shaded individuals during 2017 (second full shading season). Note that the point ' 0 ' for Pseudotsuga is higher than 2 (2.3) and thus not visible.

Fig. 7 Comparison of aboveground NSC storage and aboveground growth in three different seasons at $100 \%$ light and $6 \%$ light. The $x$-axis shows the shade : control ratio of weighted aboveground NSC concentrations after leaf fall in November (stem wood in broad-leaved, stem wood and needles in conifers; means across species $\pm \mathrm{SE}, n=9$ ). The $y$-axis shows the shade : control ratio of the annual aboveground dry matter RGR in each season. (Mean across species $\pm \mathrm{SE}, n=9$ ). SE are indicated by oval shapes. C, unshaded controls; 0 , shaded individuals during 2015 ('acclimation season', where shading started after shoot growth); 1, shaded individuals during 2016 (first full shading season); 2, shaded individuals during 2017 (second full shading season).

This article is protected by copyright. All rights reserved. 


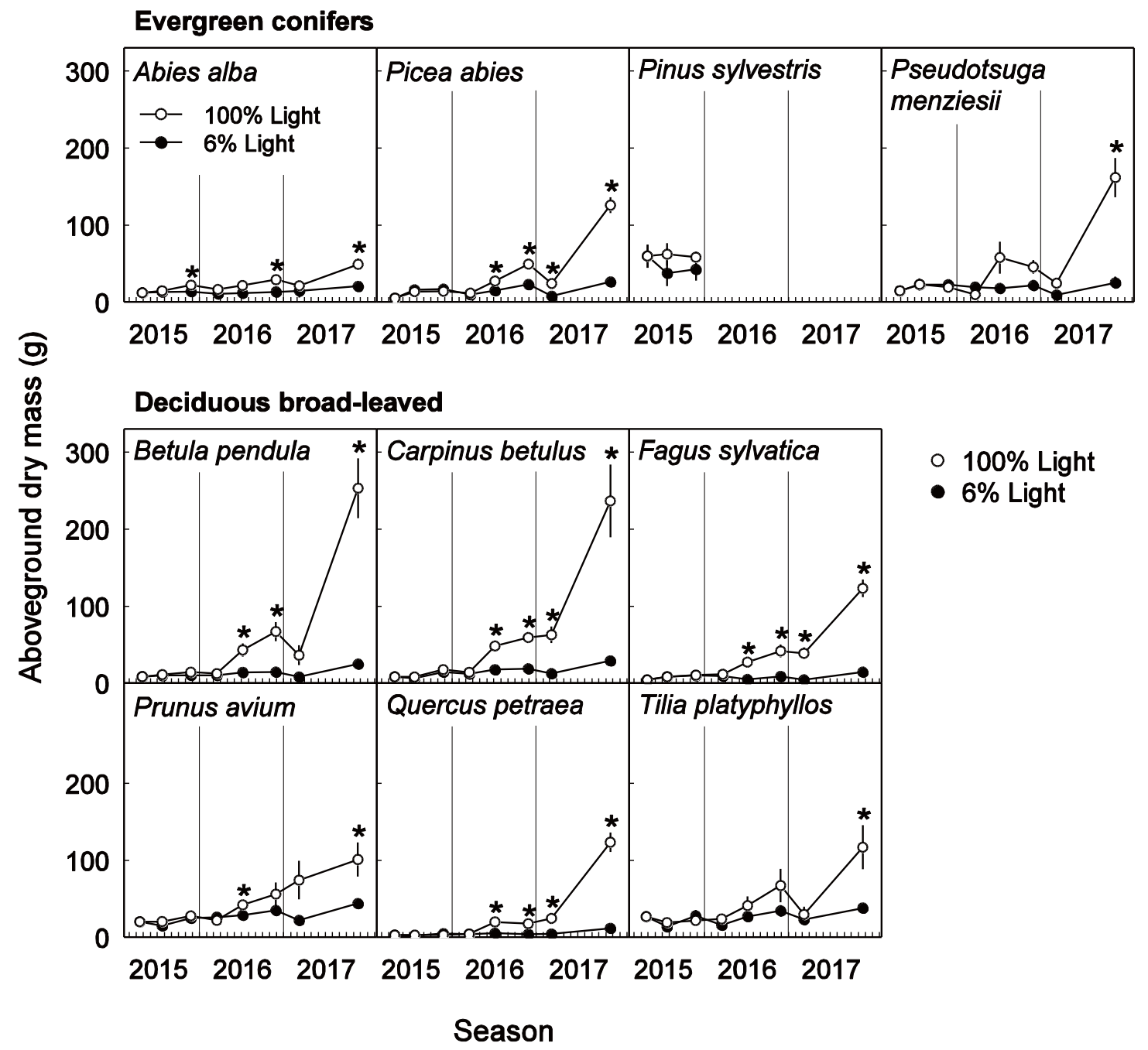

This article is protected by copyright. All rights reserved. 
Evergreen conifers

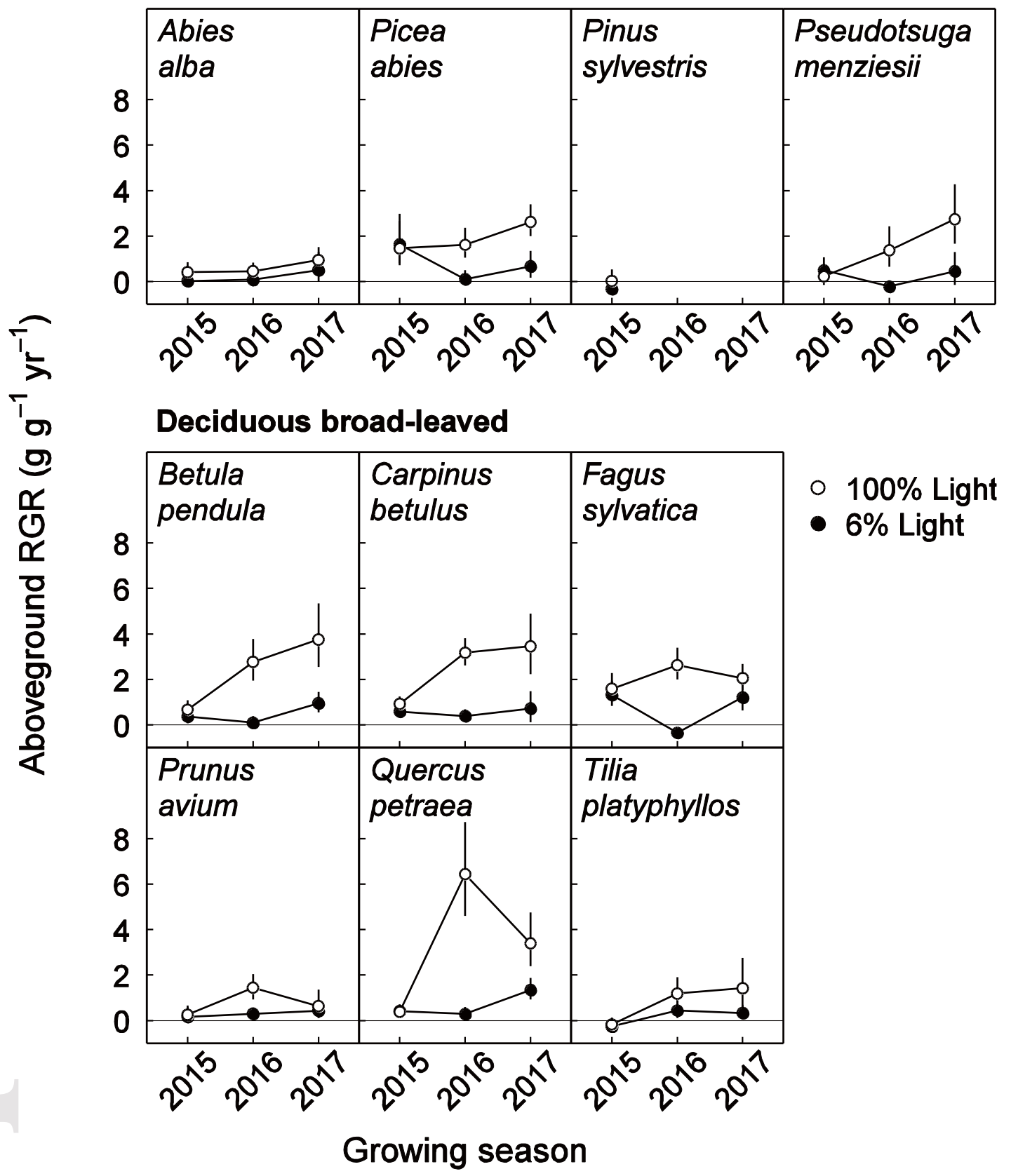

This article is protected by copyright. All rights reserved. 

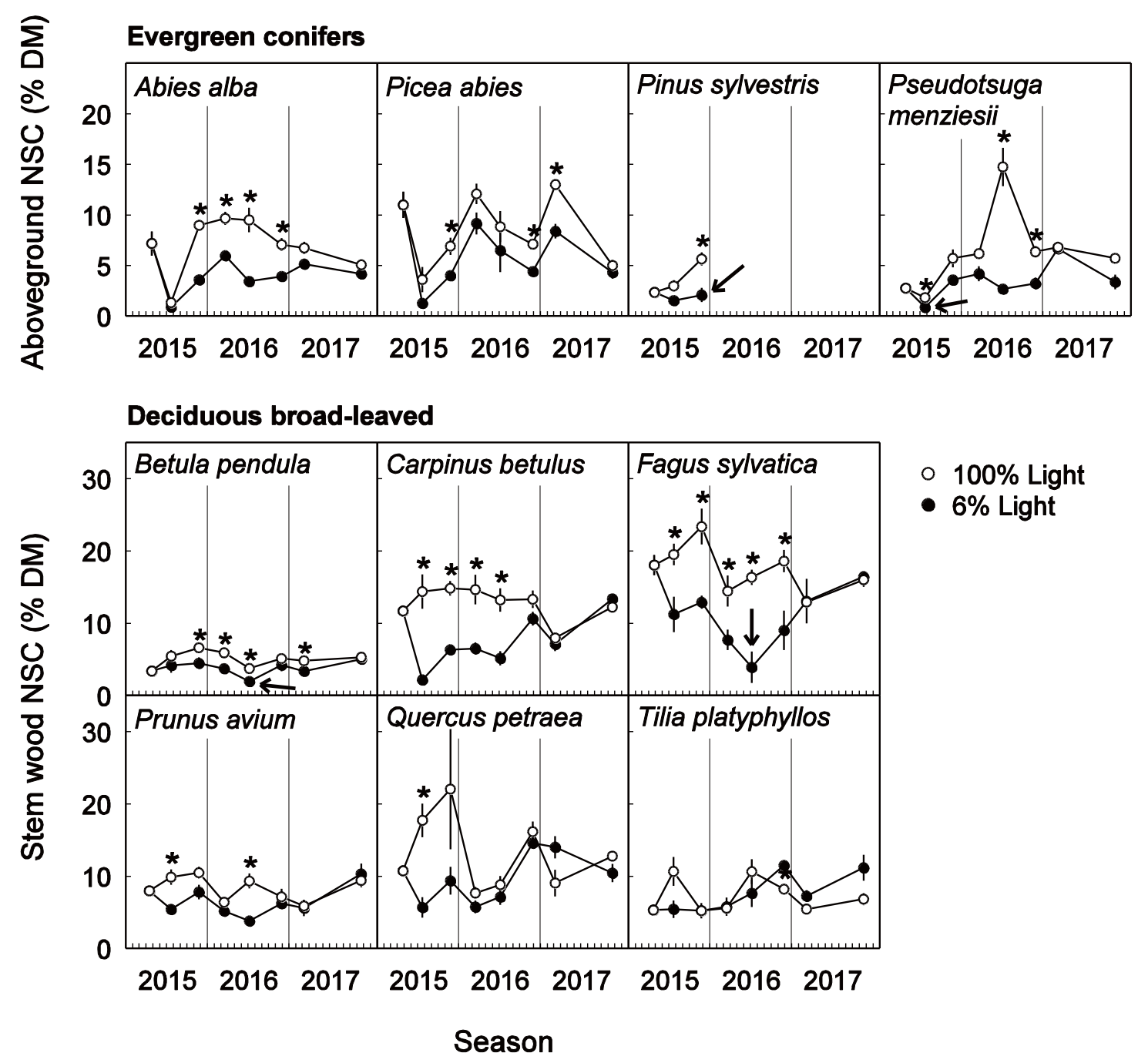

This article is protected by copyright. All rights reserved. 

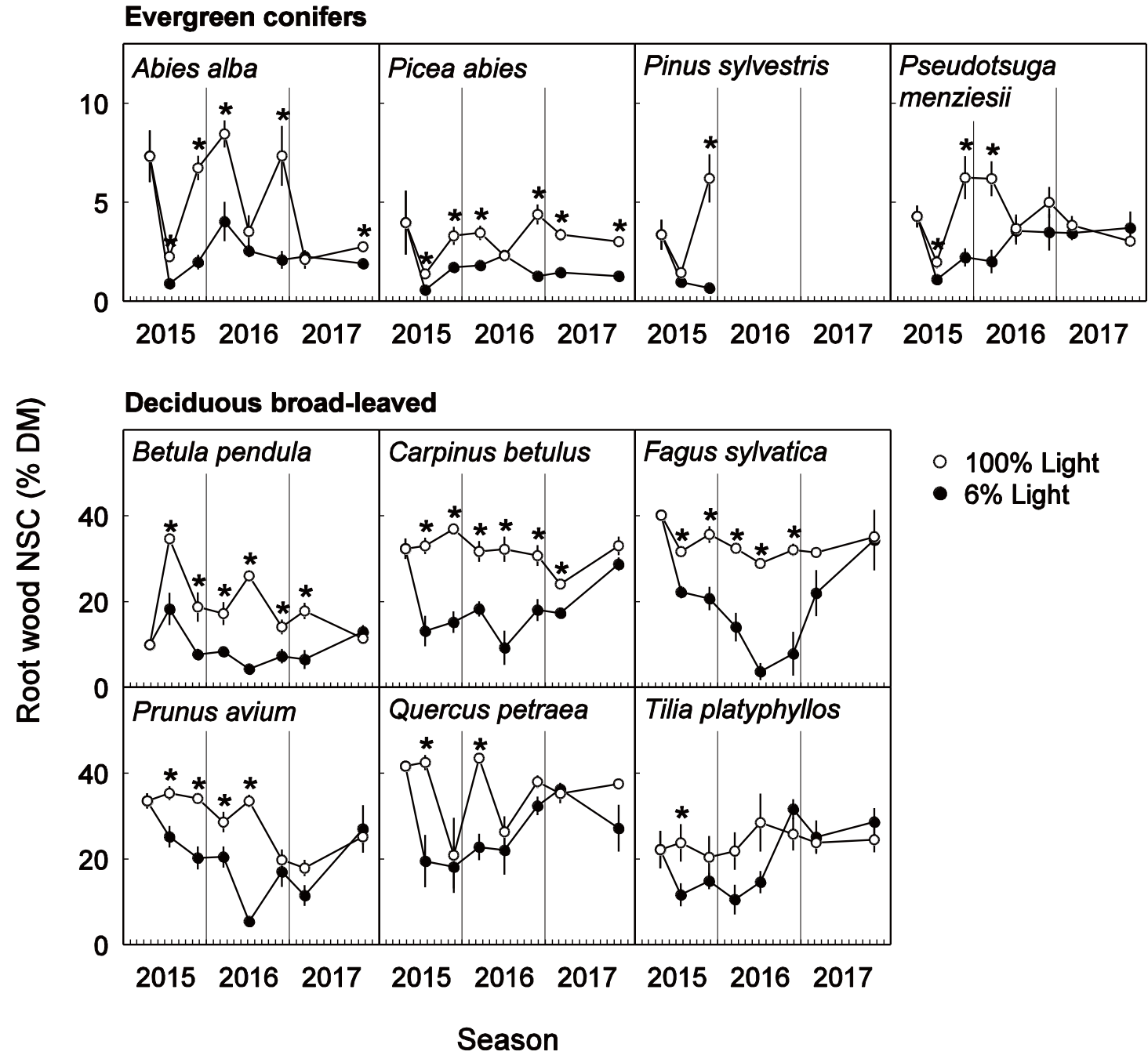

This article is protected by copyright. All rights reserved. 
(a)

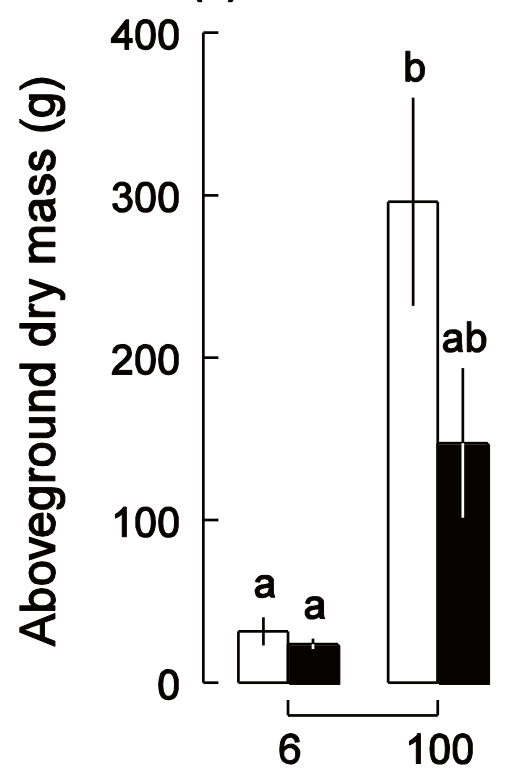

(b)

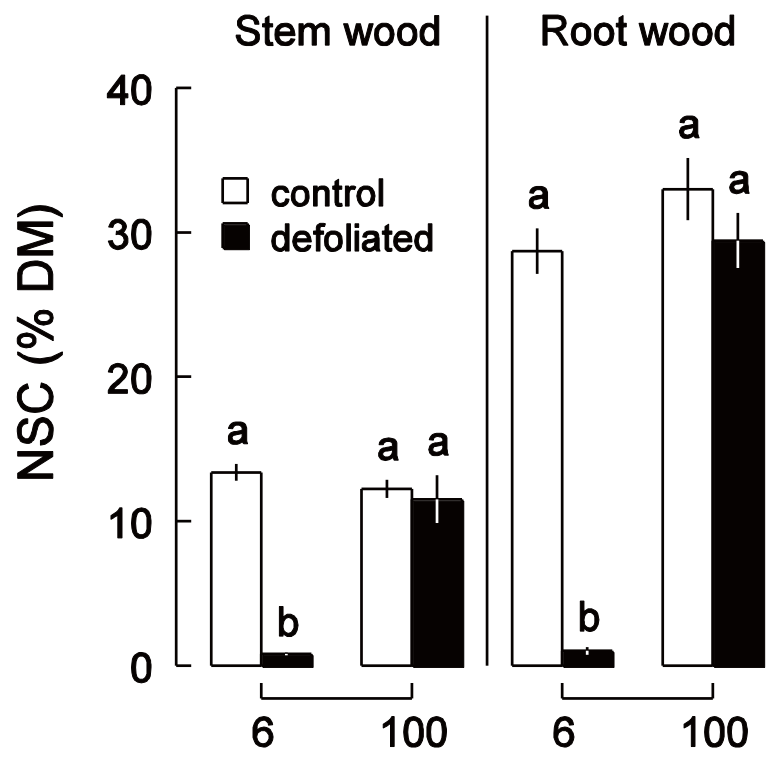

Light intensity (\%) 
Evergreen conifers

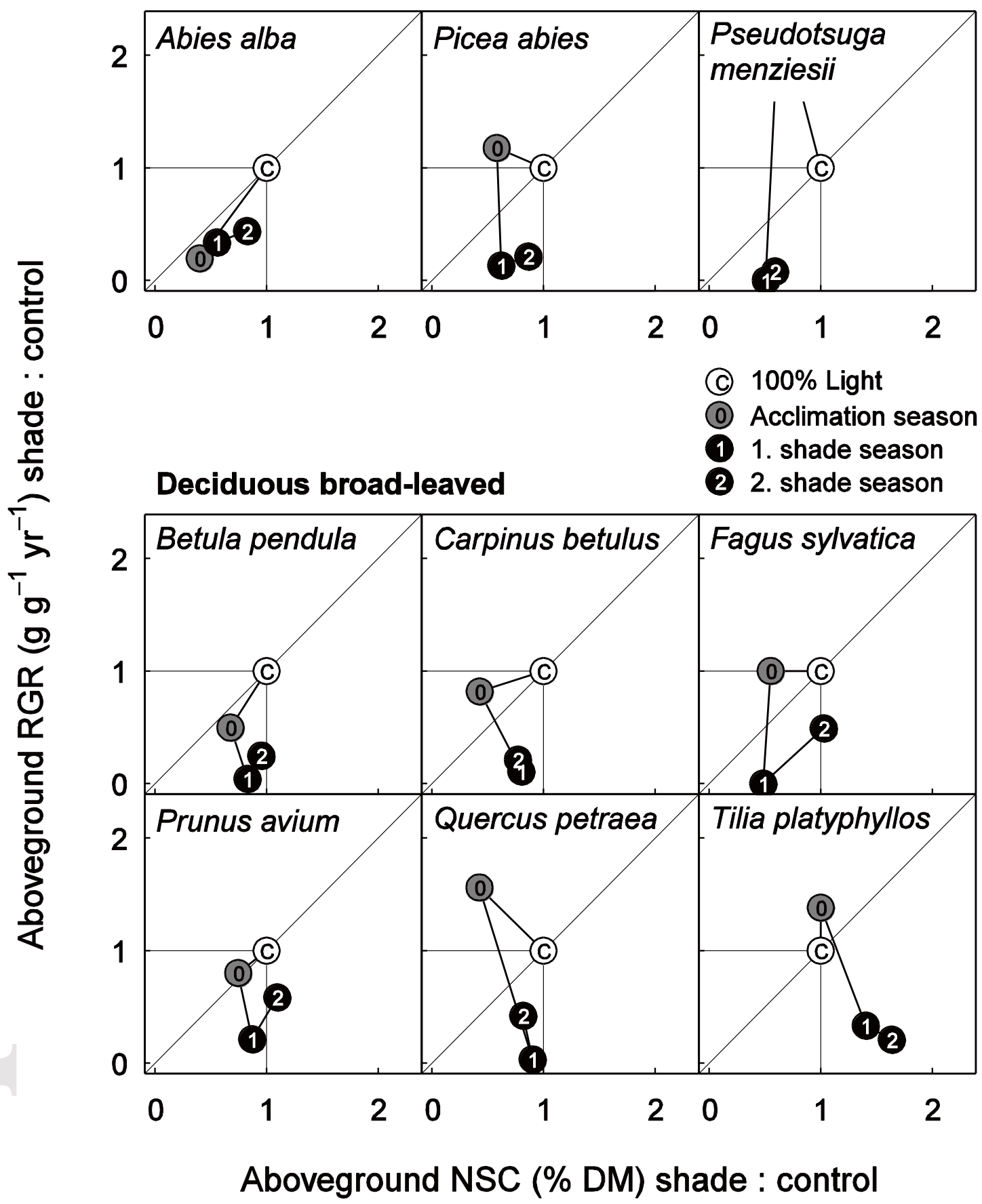

This article is protected by copyright. All rights reserved. 


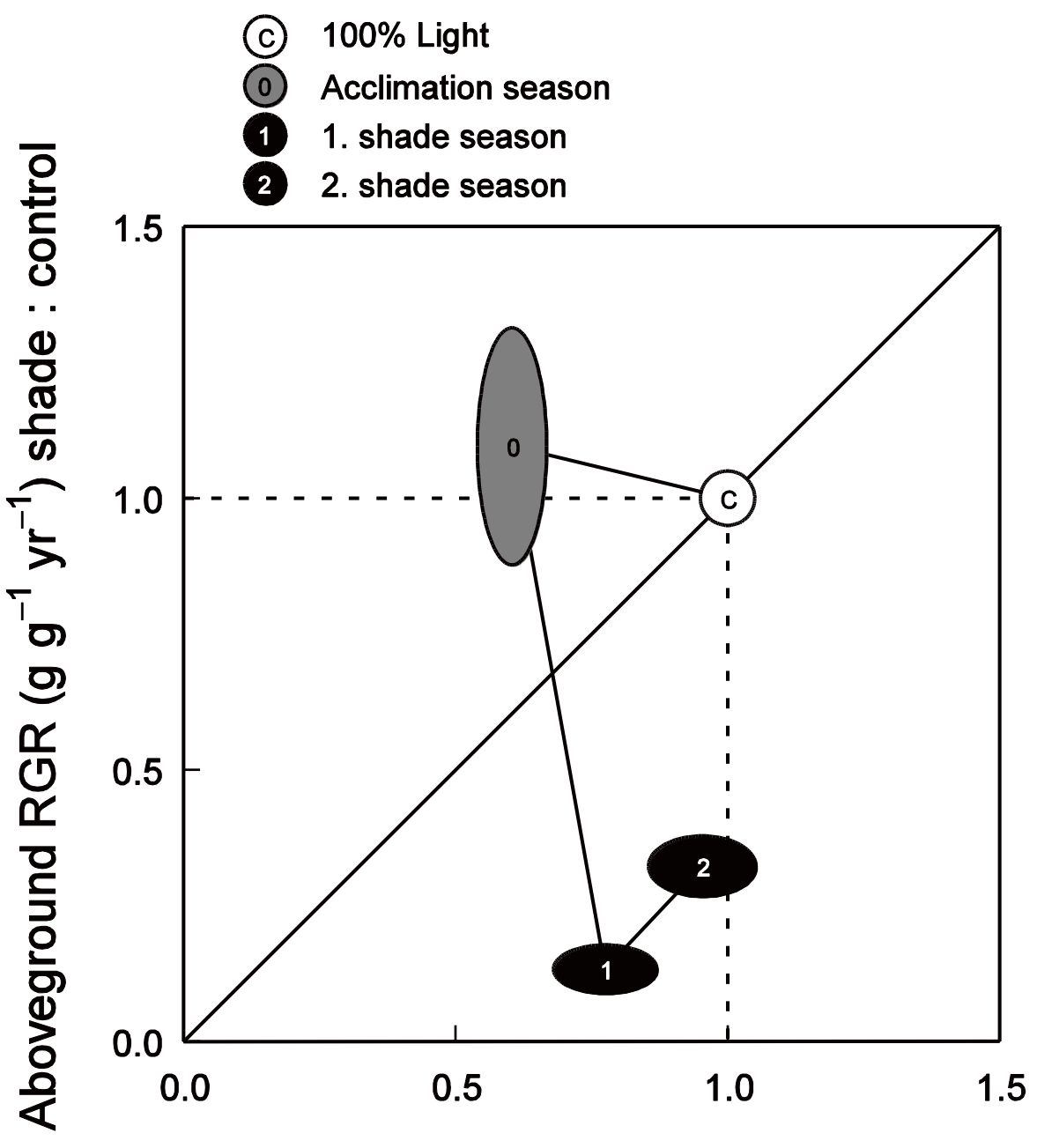

Aboveground NSC (\%) shade : control 